DOI :10.31357/fapsmst.2008.00488

\title{
Manufacture of Fruit cheese from Buffalo Milk and Papaya Pulp
}

NILMINI MAHANAMA.

M.Sc 


\section{Manufacture of Fruit cheese from Buffalo Milk and Papaya Pulp}

Nilmini Mahanama.

Thesis submitted to the University of Sri Jayewardenapura in partial fulfillment of the requirements for the award of the degree of Master of Science in Food Science and Technology on

$18^{\text {th }}$ of August 2008 
“The work described in this Thesis was carried out by me under the supervision of Prof.A.B.Bamunuarachchi and a report on this has not been submitted in whole or in part to any university or any other institution for another Degree/ Diploma."

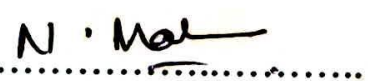

Students Signature

Date 
"I certify that the above statement made by the candidate is true and that this thesis is suitable for submission to the University for the purpose of evaluation."

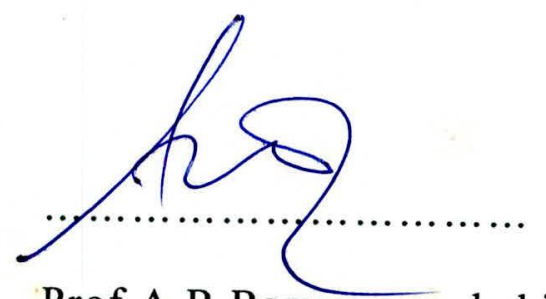

Prof.A.B.Bamunuarachchi 


\section{Content}

\section{Contents}

PAGE

List of Contents

List of Tables

List of Figures

Acknowledgement

Abstract

1. Introduction

1.1. General 01

1.2. Objectives of the study 06

2. Literature Review

2.1. Milk Lipids

2.2. Milk Proteins

08

2.3. Casein Micelles

08

2.4. Coagulation Mechanism 09

2.5. Mechanism of the acid coagulation 09

2.6. Classification of Cheese 11

2.7. Nutritional Aspect of Cheese 12

3. Material and Methods

3.1 Tests done for the qualitative analysis of samples $\quad 14$ of fresh milk 
3.2. Quantitative analysis of samples

of fresh milk

3.3. Sample Preparation $\quad 18$

3.4. Analysis of samples 20

3.4.1. Compositional Analysis 21

3.4.2. Microbiological 25

3.4.3. Sensory Evaluation $\quad 30$

4. Result and Discussion

4.1. Nutritional Evaluation 33

4.2. Microbial Evaluation 34

4.3. Sensory Evaluation $\quad 36$

5. Conclusion 56

6. References 58

7. Appendices

(II) 


\section{List of TABLes and Figures}

Page No.

1. Average chemical composition of milk of different species ( Table-1)

2. Classification of cheese based on composition ( Table-2)

3. Composition of selected Cheeses ( Table-3)

4. Results of Nutritional evaluation of cheese sample (Table-4) 33

5. Results of Microbial evaluation of cheese sample 34 ( Table-5)

6. Requirement for cheese according to the SRI LANKA 35 STANDARD 773:1987 (Specification for cheese) ( Table-6)

7. Requirement for cheese according to the SRI LANKA STANDARD 773:1987 (Specification for cheese) ( Table-7 ) 
8. Consumer Oriented Test Rank - Preference Test Statistics

Table 9

Table 10

Table 11

9. Product Oriented Testing - Quantitative Descriptive Analysis

$$
\text { Color - Statistics }
$$

\author{
Color - Statistics
}

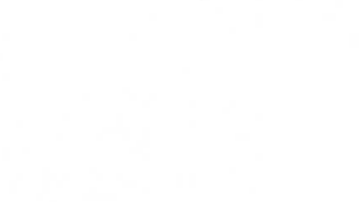

Aroma - Statistics
Table 12

41

Table 12.1

Table 12.2

Table 12.3

Table 13

Table 13.1

Table 13.2

Table 13.3
41

42

43

44

44

45

46 
Flavor - Statistics

Mouth Feel - Statistics

After Taste

1. Figure 1: Carica Papaya

2. Figure 2 : Sample of cheese 1

3. Figure 3 : Sample of cheese 2

4. Sample Preparation
Table 14

47

Table 14.1

Table 14.2

48

Table 14.3

49

Table 15

50

Table 15.1

50

Table 15.2

51

Table 15.3

52

Table 16

53

Table 16.1

53

Table 16.2

Table 16.3 
8. Consumer Oriented Testing Rank-Preference Test Statistics

$\begin{array}{ll}\text { Table } 8 & 37 \\ \text { Table } 9 & 38\end{array}$

Table $10 \quad 39$

Table $11 \quad 40$

9. Product Oriented Testing - Quantitative Descriptive Analysis

$\begin{array}{ccc}\text { Color - Statistics } & \text { Table } 12 & 41 \\ & \text { Table } 12.1 & 41 \\ \text { Table } 12.2 & 42 \\ \text { Aroma - Statistics } & \text { Table 12.3 } & 43 \\ & \text { Table 13 } & 44 \\ & \text { Table 13.1 } & 44 \\ & \text { Table 13.2 } & 45 \\ & \text { Table } 13.3 & 46\end{array}$




\section{Acknow ledgement}

The successful completion of my MSc. work was made possible by the effort of many people. I take this opportunity to express my heartful gratitude to my supervisor Prof.A.B.Bamunuarachchi for all the encouragement and proper guidance given to complete my work successfully.

My deep appreciation is extended to Academic and Non-Academic staff of Food Science \& Technology program and Veterinary Surgeons and Technical staff of Veterinary Investigation Centre Gannoruwa, the staff of Vidatha Resource Centre and the staff of the Veterinary Office-Kesbewa.

I am forever grateful to my family who helped in many way, which are too numerous to mention. 


\section{Manufacture of fruit cheese from buffalo milk and papaya pulp by Nilmini Mahanama}

\section{ABSTRACT}

Buffalo milk is rich in protein and fat compare to cow's milk. Buffalo milk is widely available in Kesbewa area. It can be easily used for the value added products like cheese, but currently rarely or almost not using buffalo milk for cheese industry in this area.

Cheese samples were prepared using buffalo milk collected from farms of the DS area Kesbewa. Papaya pulp was added to the cheese to produce a fruit cheese. It also improves the color, flavor and the nutritional value of the cheese.

Moisture, Protein and Fat content of the product, microbial and sensory properties were analyzed.

Average moisture level of the cheese is $75.06 \%$, crude protein is $9.7 \%$, Fat is $14.03 \%$ (dry basis), Dry matter is $23.73 \%$.

Recommended range of moisture is $55-80 \%$, Dry matter is 20 $45 \%$ for the soft cheese. Average moisture level and dry matter percentage was with in the acceptable range.

Microbial analysis was also with in the satisfactory level.

Sample number 01 was selected as the best sample from the sensory evaluation. 


\section{Chapter 01}

\section{Introduction}

\subsection{General}

Milk is a valuable source of nutritional substances. It is considered as the most complete of food. Through the centuries, man has wisely learnt how to use this food source in two ways.

- as a foodstuff: for direct consumption (milk as a drink);

- transformed: as an element from which it is possible to obtain dairy products (cheese, butter, yoghurt, etc.)

\section{Buffalo Milk}

Buffalo cows start producing milk after giving birth. The first liquid secreted by the udder is the colostrums, which is only used for the feeding of the calf; it is not collected as it cannot be used for the production of dairy products. The colostrums is much richer than normal milk in vitamins and immungobins, a class of proteins with an immune defensive function. After about 6 days from calving, the colostrums changes in to milk.

Buffalo cows are milked twice a day for 10 months; this period is known as the lactation period. When the buffaloes stop producing milk, it means they have entered the "dry period". 
The chemical composition of milk depend on various factors: species, breed, age of the animal, feeding, health condition, environmental factors and lactation period. Water, proteins, fat, sugars, mineral salts, vitamins and enzymes are the substances we usually find in milk.

Table-1 - Average Chemical Composition of milk of different species

\begin{tabular}{|l|l|l|l|l|l|}
\hline Species & Water & Protein & Fat & Lactose & $\begin{array}{l}\text { Mineral } \\
\text { Salts }\end{array}$ \\
\hline Buffalo & 82.2 & 4.8 & 7.5 & 4.7 & 0.8 \\
\hline Goat & 86.5 & 3.9 & 4.3 & 5.8 & 0.8 \\
\hline Ewe & 80.9 & 6 & 7.5 & 5.4 & 1.1 \\
\hline Cow & 87.5 & 3.2 & 3.7 & 4.6 & 1.0 \\
\hline
\end{tabular}

If we compare buffalo milk with cows milk, we can draw the following conclusions;

Buffalo milk is richer in fat than cows milk. The buffalo compared to the cow, produces a milk with higher percentage of proteins.

Buffalo milk is the raw material from which buffalo Mozzarella cheese is traditionally produced. 
The raw material, milk (a short life commodity) is used by cheese industry to be converted in to cheese which according to variety and storage, has a shelf life from 4-5 days up to 5-10years. The cheese industry therefore provides a useful service in extending the life of a valuable human foodstuff.

The cheese maker must consider nutrition, consumer reactions (including medical opinions) taste, aroma, texture and appearance if the cheese is to have continued marketability.

A part from water, man requires four major groups of nutrients in food, which in the past were often quoted as fat, protein, carbohydrate and salts. Modern nutritional standards are more demanding in respect of many minor components such as vitamins minerals. etc.

Divisional Secretarial area Kesbewa(Veterinary range of Kesbewa) is popular for buffalo farming and for highbred buffaloes because of that large quantities of buffalo milk is produced in this area. Most of the buffalo milk produced in this area are used for the production of curd, surplus is sold to the milk collecting centers. (eg:"Milco")specially during the rainy seasons. The shelf life of a curd pot is for seven days in room temperature and in refrigerated conditions (at $4^{\circ} \mathrm{C}$ ) it can be kept for about 14 days. But a product like cheese can be kept for longer time than curd. Cheese is an expensive product in local market. Because of that converting milk in to cheese is one method of dealing with surplus and it will provides an incentive for improving dairying as well as 